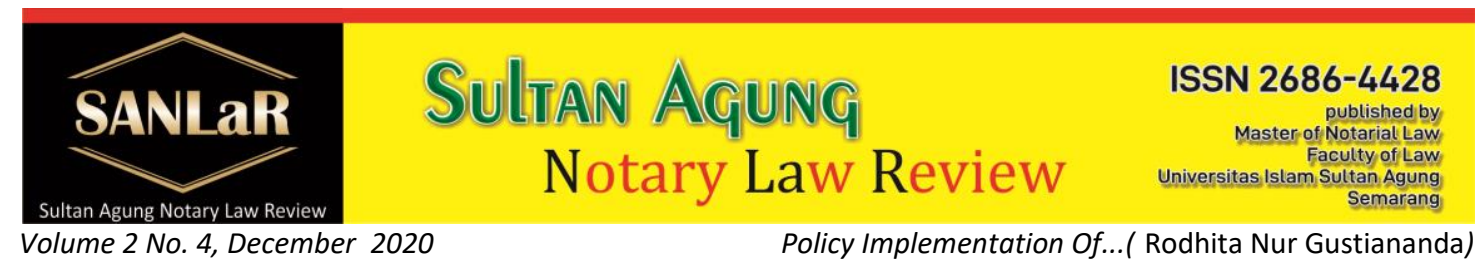

\title{
Policy Implementation of Land Value Zone Towards Transaction Value in Assets of Land Office
}

\author{
Rodhita Nur Gustiananda*), Amin Purnawan ${ }^{* *}$ and Akhmad Khisni ${ }^{* * *}$ \\ *) Students of Master of Notary Law, Universitas Islam Sultan Agung (UNISSULA) \\ Semarang, E-mail: rodhitanur.g@gmail.com \\ $\left.{ }^{* *}\right)$ Lecturer of Master of Notary Law, Universitas Islam Sultan Agung (UNISSULA) \\ Semarang \\ ${ }^{* * *}$ Lecturer of Master of Notary Law, Universitas Islam Sultan Agung (UNISSULA) \\ Semarang
}

Abstract. The purpose of this research is to: 1) To find out what are the regulations governing Land Value Zones in Indonesia, 2) To find out the implementation of the Land Value Zone policy on Transaction Value in deeds at the Kuningan Regency Land Office. The data used in this study are primary materials, secondary materials and testier materials that can support the assessment, which are then analyzed using the empirical juridical method. Based on the results of data analysis, it is concluded that: 1) The regulation regarding Land Value Zones in Indonesia has not yet been specifically regulated regarding the determination of Land Value Zones or land value information, but the community also does not really understand the land values based on or determined by the Land Value Zones In the Kuningan Regency Land Office as well as the Kuningan Regency Regional Regulation, it also does not regulate market value or the Land Value Zone policy which in the end has different policies between agencies. 2) In terms of the legal substance related to the Land Value Zone, Kuningan Regency has not realized it due to clashes between employees regarding the rules.

Keywords: Policy Implementation; Land Value Zone; Deed.

\section{Introduction}

Humans are social creatures who have various necessities of life and in nature fulfill those needs, it is impossible to produce it themselves. Humans are always in touch with each other to meet the needs of life. ${ }^{1}$ Humans have a need for life, one of the

\footnotetext{
${ }^{1}$ Basyir, Ahmad Azha. (2000). Asas-asas Hukum Muamalah, Edisi Revisi. Yogyakarta: UII Press. p. 11.
} 
human needs is land. Land is a resource factor that has a strategic role in human life activities. Needs land, especially in urban areas, always increases with the increase in population. On the other hand, one of the most basic characteristics of land is that its spatial location cannot be moved and its total physical stock is relatively fixed. There is also a close relationship between value or price and location, where land in central trade or market areas has a high degree of accessibility and mobility so that its value is very high compared to land in suburban areas.

In Indonesia, land has a very important meaning for the life of its people. Land that provides daily life, a place to build houses to provide for the system of life and children and grandchildren, which in the end is also the land where people are buried after death as the final resting place. ${ }^{2}$

Agrarian issues are issues that require special attention and regulation, clearly and as soon as possible. Because of this, Article 33 paragraph 3 (three) of the 1945 Constitution determines as follows: "the earth, water and natural resources contained therein shall be controlled by the State and are used to the greatest benefit of the people". This provision becomes the basis for the Indonesian government to form various laws and regulations in the land / agrarian sector.

The provisions of Article 33 paragraph 3 (three) are imperative, that is, they contain orders to the state so that the earth, water and natural resources contained therein, which are placed under the control of the country, are used to create prosperity for all Indonesian people. Thus, aim from the control by the state over the earth, water and natural resources contained therein is to realize the greatest prosperity of the Indonesian people. ${ }^{3}$

Further developments, the government made policies related to land, namely the Land Value Zone (ZNT). The Land Value Zone (ZNT) is a polygon depicting relatively equal land values from a group of land parcels in it, whose boundaries can be imaginary or real in accordance with land use and have differences in value from one another based on officer analysis with the market price comparison method and cost. ${ }^{4}$

According to Maria, SW Sumardjono, because the nature of land is scarce and limited, and it is a basic need of every human being, in essence the land issue is a problem that deeply touches justice. But it is not always easy to devise a land policy that is felt to be fair to all parties. ${ }^{5}$ The Government issued a policy regarding land service rates as stipulated in the Government Regulation of the Republic of Indonesia Number 128 of 2015 concerning Types and Rates for Types of Non-Tax State Revenues that apply to the Ministry Agrarian and Spatial Planning / National Land Agency which includes provisions regarding Land Value Zones (ZNT).

\footnotetext{
${ }^{2}$ Susanti, Nur. (2008). Praktir Jual Beli Tanah Di Bawah Tangan Dan Akibat Hukumnya Di Kecamatan Boa Kabupaten Kudus. Thesis, p. 1.

${ }^{3}$ Santoso, Urip. (2012). Hukum Agraria:kajian Komprehensif. Edisi I. Jakarta: Kencana Prenada Media Group. p.32

${ }^{4}$ BPN, R., (2012). Peta Zona Nilai Tanah Riview.

${ }^{5}$ Sumardjono, M.S., (2009). Penelitian Hukum Normatif (1 ed). Jakarta: PT.Raja Grafindo Persada. p.2
} 
The implementation of ZNT (Land Value Zone) as the determination of Non-Tax State Revenue (PNBP) results in higher costs that must be incurred by the community. This has an impact on people who feel burdened, especially the middle to lower class, with higher expenditures. The focus of ZNT's policy studies is interesting and important to discuss both the concept of positive law and its implementation in relation to the importance of Land Value Zones (ZNT) as a guarantee of legal certainty in land services, the function of Land Value Zones (ZNT) as legal certainty in determining the basis for the imposition of PNBP in the land sector, as well as the implementation of Land Value Zones (ZNT) in services of transfer of land rights and its relation to the determination of PNBP. This is related to the basic idea of law that includes the value of benefit, certainty and legal justice, especially for the community. Meanwhile, prior to the issuance of Government Regulation Number 128 of 2015 and Permen ATR / KBPN Number 8 of 2015 the determination of PNBP was based on the NJOP as a calculation basis for determining PNBP in the transfer of land rights.

\section{Research Methods}

Research conducted by the author uses an empirical juridical approach, namely in analyzing the problem, it is carried out by combining legal materials (which are secondary data) with primary data obtained in the field, namely regarding the land value zone policy in the National Land Agency of Kuningan regency.

\section{Results and Discussion}

\subsection{Legislation concerning Land Value Zones}

Regulations are provisions that bind members of community groups, are used as guidelines, order, and control behavior that is appropriate and acceptable: every member of the community must obey the applicable rules; or measure, a rule that is used as a yardstick to judge or compare something.

The fifth precept in Pancasila says that "Social Justice for all Indonesian people" as it sounds, the meaning of the fifth precept describes justice that must be obtained by the entire community. This justice applies to all aspects of life, including the rights and obligations of each individual.

In connection with the issue of the Land Value Zone policy is none other than the community, but not all can be called the community, we must be able to distinguish which people already know the rules or not, this must be considered again because not all children understand the rules so it must be strengthened by regulations Legislation to Regional Regulations (PERDA). In Indonesia, there are several regulations regarding child protection, including:

1. Government Regulation of the Republic of Indonesia Number 24 of 1997 concerning Land Registration, Government Regulation of the Republic of 
Indonesia Number 13 of 2010 concerning Types and Rates of Types of Non-Tax State Revenues Applicable to the National Land Agency.

2. Republic of Indonesia Government Regulation Number 17 of 2015 concerning the Ministry of Agrarian Affairs and Spatial Planning.

3. Government Regulation of the Republic of Indonesia Number 128 of 2015 concerning Types and Rates of Non-Tax State Revenues Applicable to the Ministry of Agrarian Affairs and Spatial Planning / National Land Agency.

4. Kuningan Regency Regional Regulation Number 15 of 2010 concerning Regional Taxes.

3.2 Implementation of Land Value Zones on Transaction Value in deeds at the Kuningan Regency Land Office

Amendments to Government Regulation Number 13 of 2010 to Government Regulation Number 128 of 2015, one of the changes to this Government Regulation that is enhanced is the regulation related to certain parties. One of the subjects of certain parties, namely the poor community, received an incentive in the form of IDR 0 , - (zero rupiah) for the first land certification in the form of measuring the boundaries of land parcels, committee $A$ land inspection and first land registration.

In line with the aforementioned rights, the government makes products related to land, namely the Land Value Zone (ZNT). The Land Value Zone (ZNT) is a polygon that describes the land value that is relatively the same from a group of land parcels in it, whose boundaries can be imaginary or real according to land use and have different values from one another based on the official analysis of the market price and cost comparison method. ${ }^{6}$ The purpose of the Land Value Zone (ZNT) itself is to identify land values by clearly defining the boundaries of ownership of land rights in the form of a sketch / map.

The Land Value Zone (ZNT) issued by the Ministry of ATR / BPN is a polygon depicting relatively equal land values from a set of land parcels within, whose boundaries can be imaginary or real according to land use. The difference in value between one land and another is based on the analysis of officers using the market price and cost comparison method. The information displayed by ZNT is the value of land in the "empty" state, not including the value of objects attached to it.

Based on Government Regulation Number 128 of 2015 concerning Types of Non-Tax State Revenues applicable to the Ministry of Agrarian Affairs and Spatial Planning / National Land Agency there are several land services that refer to the value of land obtained from the Land Zone Map. The Land Value Zone Map (ZNT) can also be a reference at the stages of planning activities in land acquisition for development in accordance with Act No. 1 of 2012 concerning Land Acquisition for Development for public interest and its implementing regulations. 
3.3 Implementation of the Land Value Zone price at the Kuningan Land Office.

Applicants can receive the ideal product results in one day and a maximum of three working days. This Land Value Zone serves as the basis for the value per meter in determining the value of the object of transfer of land rights, where the Land Value Zone greatly influences the inclusion of Non-Tax State Revenues within the National Land Agency based on Government Regulation of the Republic of Indonesia Number 128 of 2015 concerning kind and Tariffs. Type of Non-Tax State Revenue Article 16 paragraph 9 (1) and paragraph (2), namely:

1. The tariff for the first-time Land Registration service as referred to in Article 15 letter $a$ is in the form of registration services:

a. Decree on Extending Land Rights for Business Use Rights, Building Use Rights, or Term Use Rights; and

b. Decision on Renewal of Land Rights for Business Use Rights, Building Use Rights, or Term Use Rights, is calculated based on the formula T

$=(2 \%$ ox land value $)+$ IDR 100.00.00

2. The Tariff for Land Registration Data Maintenance Services as referred to in Article 15 letter $b$ is in the form of Registration Services for Transfer of Transfer of Land Rights for Individuals and Legal Entities, calculated based on the formula $T=(1 \%$ ox Land Value) + IDR 50,000.00.

It is said to have an effect on Non-Tax State Revenues because previously the Land Value in Article 16 paragraphs 1 and 2 used the Sales Value of Tax Objects (NJOP) in SPPT PBB (Tax Returns for Land and Building Tax Payable) which is calculated to be smaller than the Land Value Zone which can be cause losses to non-tax state revenue. Meanwhile, for people who do not have a land title certificate, it is rather difficult to get information on land value because the Kuningan Regency Land Office cannot provide a system or website related to information on land value.

According to Oktaviada Jaka P, A.Md., as PPNPN subsection of government land acquisition and designation facilitation:

"Incidentally, in Kuningan, the Land Value Zone is not yet comprehensive, so the values are not evenly distributed yet all in the sub-district, in the village, are not filled. Of the 36 sub-districts, only 16 sub-districts from one district have a Land Value Zone. In 16 sub-districts, there are several villages whose values are still empty, for example in Cilimus, Bandorasawetan village, the values have not been mapped. Meanwhile, the National Land Agency of Kuningan Regency plans in the future one value for each land value information is the emergence of the BPN but one of the obstacles is that there is no communication from various agencies and parties related to the application of the Land Value Zone in Kuningan Regency. "

3.4 Implementation of the Land Value Zone price at the Kuningan Regency Regional Revenue Management Agency

Based on the results of field research to be precise at the Kuningan Regency Regional Revenue Agency Office. Retribution is a source of income that is most likely to be 
developed in accordance with the creativity of the respective regional governments, because they have the freedom to collect fees. This freedom means that because the field retribution is related to the replacement of services / facilities provided by the region, the collection of user fees can be done several times as long as the mandatory levies still use the services provided. In the government sector, there are many problems and affairs that must be resolved in relation to the increasingly rapid development carried out by the central and regional governments.

The largest local revenue (PAD) is obtained from the local tax and local levies sector. Where that local taxes are local government levies where the implementation is carried out by the Regional Revenue Service on people or entities based on the applicable laws and regulations for the financing of their regional households. Whereas the definition of regional retribution can be interpreted as levies made by the government as a result of contra-performance provided by the regional government or the payment is for achievements or services provided by the local government which are directly enjoyed by the community and its implementation is based on regulations. According to Luky Gandara, S.STP who previously served as Head of the Determination and Objection Section of PPB and BPHTB

"For Tax Returns Payable (SPPT) in Land and Building Tax (PBB) to determine the value that is not far from determining the Land Value Zone in Kuningan Regency, the determination is for 2 purposes, namely a tax reference for the Sales Value of Tax Object (NJOP) for SPPT. PBB and secondly for the determination of NJOP for Land and Building Acquisition Fee (BPHTB). "

This regional tax collection must comply with the provisions that the tax field to be collected has not been cultivated by the government level above it. Before reforming local taxes, quite a number of types of taxes were made by each region. For this reason, so that local taxes are more effective and efficient, then in 1997. The government has reformed the existing local tax and retribution regulations to adapt them to national economic developments. (Pangstuti, 2013)

\subsection{Implementation of the Land Value Zone Price on the Transaction Value in the Sale and Purchase Deed in Kuningan Regency}

According to Woll, policy is a government activity to solve problems in society either directly or through various institutions that affect people's lives.

Based on the results of research in the field, precisely at the Kuningan Regency Land Office or the National Land and Agrarian Affairs Agency regarding the effectiveness of the Land Value Zone in the Land Office on the Transaction Value in Deeds in Kuningan Regency, for people who wish to transfer their land rights over their ownership certificate. through the interview method and there are some data that are only provided because the Land Value Zone is not yet perfect to be implemented in Kuningan Regency because each of these offices and agencies has their respective policies. 
There is a table of differences in Transaction Prices according to ZNT and Prices according to ZNT and Transaction Prices in the PPAT Sale and Purchase Deed, especially in Ciporang Village, Kuningan District, Kuningan Regency.

\begin{tabular}{|c|c|c|c|c|c|}
\hline No. & $\begin{array}{l}\text { Area } \\
(\mathrm{m} 2)\end{array}$ & $\begin{array}{l}\text { Price ZNT / } \\
\text { M2 (Rp) }\end{array}$ & $\begin{array}{l}\text { Transaction prices } \\
\text { In accordance with } \\
\text { ZNT (Area x ZNT } \\
\text { Price) / (Rp) }\end{array}$ & $\begin{array}{l}\text { Price } \\
\text { Transactio } \\
\mathrm{n} \text { in AJB ( } R p)\end{array}$ & $\begin{array}{l}\text { Market Value in } \\
\text { BPHTB (Rp) }\end{array}$ \\
\hline 1. & 220 & IDR 250.000, - & IDR 55,000,000 & IDR 150,000,000, - & IDR 150,000,000, - \\
\hline 2. & 265 & IDR 550.000, - & IDR 145,750,000, - & IDR 650,000,000, - & IDR 650,000,000, - \\
\hline 3. & 650 & $\begin{array}{l}\text { IDR 1.500.000, } \\
-\end{array}$ & IDR 975,000.00, - & IDR 2,275,000,000, - & IDR 2,275,000,000, - \\
\hline 4. & 420 & IDR 635,000, - & IDR 266,700.00, - & IDR 1,200,000,000, - & IDR 1,200,000,000, - \\
\hline 5. & 306 & IDR 760,000, - & IDR 273,600,000, - & IDR 360.000.000, - & IDR 360.000.000, - \\
\hline
\end{tabular}

Based on the table above, it can be seen that the transaction value in the deed is very far from the ZNT determined by the Land Office. There are differences in the provisions between these offices or agencies. Whereas the policy at the Kuningan Regency Land Office for determining the Land Value Zone is only for determining the PNBP paid by the applicant for the process of transferring names in the sale and purchase deed that they do, but the policy at the Regional Revenue Management Agency for determining Land Value Zones is not fixated on the Land Value Zones in raised by the system in the Land Office but they have several teams that work with villages and sub-districts in Kuningan District to determine Land Value Zones in various villages or wards in Kuningan District.

According to Luky Gandara, S.STP. previously served as Head of the Determination and Objection Section of PPB and BPHTB.

"Due to constraints, we also do not know the Land Value Zone applied by the National Land Agency and I also do not want to and cannot comment on the situation there, but at the Regional Revenue Management Agency office here it is not comprehensive regarding the determination of the Land Value Zone."

Meanwhile, according to Udin Saprudin, SH., Served as the Sub-Section for Government Land Use and Land Appraisal.

"From us, especially the National Land Agency, you are fixated on regulations at the center, namely provincial regulations, so we have not been able to cooperate with the regions due to constraints on the policies they have made." 
Quoted from the results of the interview above based on Kuningan Regency Regional Regulation Number 15 of 2010 concerning Regional Taxes in Article 74 paragraph 3 which reads:

"If the Tax Object Acquisition Value as referred to in paragraph 2 letter a to letter $n$ is unknown or lower than the NJOP used in the imposition of Land and Building Tax in the year the acquisition was made, the basis for imposition is Land and Building Tax NJOP."

Meanwhile, the Kuningan Regency Regional Revenue Management Agency does not determine the transaction value to determine BPHTB tax referring to the Kuningan Regency Regional Regulation Number 15 of 2010 concerning Regional Tax Article 74 paragraph 3 they determine it by the market value that occurs in the area or villages or sub-districts by surveying the area.

It can be concluded from the statements of the two parties with different agencies that there is an inconsistency and harmony with regard to a policy provision for the Land Value Zone for the transaction value applied by the Kuningan Regency Land Office, the National Land Agency and Spatial Planning Agrarian Affairs, none of which correspond to the transaction price in the Sale Deed. Purchases made by the Official for Making Land Deeds so that these conditions are not fulfilled or do not run effectively and efficiently.

\section{Closing}

\subsection{Conclusion}

Based on the research results, the following conclusions can be drawn:

1. The regulation regarding Land Value Zones in Indonesia currently has not been specifically regulated regarding the determination of the Land Value Zones or information on the land value, but the community does not really understand the land values based on or determined by the Land Value Zones in the Kuningan Regency Land Office as well as the Regulations The Kuningan Regency area also does not regulate market value or Land Value Zone policies, which in the end have their respective policies.

- The legal system in Friedman's view consists of three components, namely the legal structure component, the legal substance component and the legal culture component. Legal structure is the body, framework, and eternal form of a system. From the perspective of the legal structure, it is not very good because each policy is not one door or one rule between agencies, especially the Kuningan Regency National Land Agency and the Kuningan Regency Regional Revenue Management Agency. In terms of the legal substance related to the Land Value Zone, 
Kuningan Regency has not yet realized it due to clashes between employees regarding regulations.

\subsection{Suggestion}

1. The rules regarding the Land Value Zone policy in Indonesia have not been specifically regulated in it and neither is the Regional Regulation in Kuningan Regency which should be centralized to provide information related to Land Value Zone policies and likewise by cooperating with regions so that policies are centered with regions referring to one and adapted to regional conditions, especially Kuningan District.

2. The implementation of the Land Value Zone Policy on the value of transactions in deeds at the Kuningan Regency Land Office is not very good due to lack of communication and knowledge of employees and officials.

\section{References}

Books:

[1] Basyir, Ahmad Azha. (2000). Asas-asas Hukum Muamalah, Edisi Revisi. Yogyakarta: UII Press.

[2] Susanti, Nur. (2008). Praktir Jual Beli Tanah Di Bawah Tangan Dan Akibat Hukumnya Di Kecamatan Boa Kabupaten Kudus. Thesis page 1.

[3] Santoso, Urip. (2012). Hukum Agraria:kajian Komprehensif. Edisi I. Jakarta: Kencana Prenada Media Group.

[4] BPN, R., (2012). Peta Zona Nilai Tanah Riview.

[5] Sumardjono, M.S., (2009). Penelitian Hukum Normatif (1 ed). Jakarta: PT.Raja Grafindo Persada. 